\title{
Aplikasi Capital Budgeting dalam Penentuan Keputusan Investasi Kamar dan Ballroom Di Hotel Panorama Lembang
}

\author{
Wishnu Wardhana* \\ Sekolah Tinggi Pariwisata Bandung, Indonesia ${ }^{1,2}$ \\ Email: wisnuwardhana@stp-bandung.ac.id
}

\begin{abstract}
This research's title is "Applications of Capital Budgeting Method in Feasibility Study of Rooms and Ballroom Investment at Hotel Panorama Lembang", the purpose of this research are to know the feasibility of hotel investment based on financial projection aspect which using Capital Budgeting Method at Hotel Panorama Lembang. The feasibility of investment evaluate by the tools of capital budgeting model, which is have aspect of Discounted Payback Period, Net Present Value, Internal Rate Of Return, and Profitability Index in Hotel Panorama Lembang. The results of this research from the financial projection evaluated with the tools of capital budgeting evaluation which have the results can be seen that investment is feasible, as calculated by the method of discounted payback period is 8 years and 2 months based on hotel evaluation and 6 years and 11 months based on writer's evaluation, net present value in positive result (NPV > 0) in the amount of Rp. 1.743.693.325 , Internal Rate of Return is higher than the discounted factor of $12 \%$ in the amount of $23.9303 \%$, profitability index is in positive result higher than 1 . Based upon this calculation summarised that the feasibilty of investment based on financial projection are accepted. Based on the evaluation from the capital budgeting method, the criteria of investment at Hotel Panorama Lembang are accepted. The management used the methods which doesn't improve a good result in feasibility. Methods that used by the author more improve a good result in investing decisions, because using a selection of forecasting methods for future revenues. The author used a time series forecasting methods to improve more revenues for hotel. This forecasting method can provide the closest forecast result and the highest rate of accuracy. The author recommends to the management of Panorama Hotel Lembang to continue and accepted the investment of new rooms and ballroom. Considering the result of a feasebility study with a capital budgeting methods are accepted. The author also recommends to the management of Panorama Hotel Lembang to use a proper forecasting methods, such as time series methods.
\end{abstract}

Keywords: Financial Projection, Capital Budgeting

Abstrak

Judul penelitian ini adalah "Aplikasi Metode Penganggaran Modal dalam Studi Kelayakan Investasi Kamar dan Ballroom di Hotel Panorama Lembang", tujuan penelitian ini adalah untuk mengetahui kelayakan investasi hotel berdasarkan aspek proyeksi keuangan yang menggunakan Metode Penganggaran Modal dengan menggunakan Metode Penganggaran Modal di Hotel Panorama Lembang. Kelayakan investasi dievaluasi dengan alat model penganggaran modal, yang memiliki aspek Discounted Payback Period, Net Present Value, Internal Rate of Return, dan Indeks Profitabilitas di Hotel Panorama Lembang. Hasil penelitian ini dari proyeksi keuangan dievaluasi dengan alat evaluasi penganggaran modal yang memiliki hasil dapat dilihat bahwa investasi layak, karena dihitung dengan metode discounted payback period adalah 8 tahun 2 bulan berdasarkan evaluasi hotel dan 6 tahun dan 11 bulan berdasarkan evaluasi penulis, nilai sekarang bersih dalam hasil positif (NPV> 0) sebesar Rp. 1.743.693.325, Tingkat Pengembalian Internal lebih tinggi dari faktor diskon $12 \%$ dalam jumlah $23.9303 \%$, indeks profitabilitas dalam hasil positif lebih tinggi dari 1. Berdasarkan perhitungan ini diringkas bahwa kelayakan investasi berdasarkan proyeksi keuangan diterima. Berdasarkan evaluasi dari metode penganggaran modal, kriteria investasi di Hotel Panorama Lembang diterima. Manajemen menggunakan metode yang tidak meningkatkan hasil yang baik dalam kelayakan. Metode yang digunakan oleh penulis lebih meningkatkan hasil yang baik dalam keputusan investasi, karena menggunakan pilihan metode perkiraan untuk pendapatan masa depan. Penulis menggunakan metode perkiraan waktu untuk meningkatkan pendapatan hotel. Metode peramalan ini dapat memberikan hasil perkiraan terdekat dan tingkat akurasi tertinggi. Penulis merekomendasikan kepada manajemen Panorama Hotel Lembang untuk melanjutkan dan menerima investasi kamar dan ballroom baru. Mempertimbangkan hasil studi kelayakan dengan metode

* Corresponding author

Received: February 03, 2018; Revised: April 05, 2018; Accepted: June 21, 2018 
penganggaran modal diterima. Penulis juga merekomendasikan kepada manajemen Panorama Hotel Lembang untuk menggunakan metode peramalan yang tepat, seperti metode deret waktu.

Kata kunci: Proyeksi Keuangan, Penganggaran Modal

\section{A. PENDAHULUAN}

Adanya Peraturan Pemerintah (Perda) Kota Bandung Barat untuk menaikkan Pendapatan Asli Daerah (PAD) pada sektor pariwisata, merupakan salah satu faktor pendorong Hotel Panorama Lembang untuk melakukan penambahan asset. Peraturan Daerah tersebut ditangkap oleh pihak manajemen Hotel sebagai suatu peluang usaha untuk meningkatkan pendapatan (revenue) nantinya. Dengan adanya Peraturan Daerah tersebut akan menarik lebih banyak wisatawan untuk datang ke daerah Bandung, khususnya daerah Bandung Utara dan hal ini akan berdampak pula pada bertambahnya jumlah permintaan kamar maupun fasilitas konvensi di Hotel Panorama Lembang. Hal ini yang mendukung keputusan dewan direksi dan manajemen Hotel Panorama Lembang untuk melakukan penambahan asset berupa penambahan 16 unit kamar hotel dan perluasan ballroom sebagai fasilitas di Hotel Panorama Lembang. Keputusan dewan direksi dan manajemen Hotel Panorama Lembang tidak semata-mata hanya merujuk kepada Peraturan Daerah yang ada, akan tetapi didukung juga dengan positioning permintaan di Hotel Panorama Lembang pada tahun 2014. Pada proses penelitian penulis berhasil menganalisis positioning dari Hotel Panorama Lembang yang bersumber dari data Market Share tahun 2014. Data market share Hotel Panorama Lembang kemudian dibandingkan dengan actual market share yang ada dan para kompetitor dari Hotel Panorama Lembang pada tahun 2014 yang penulis sajikan pada tabel berikut.

Berangkat dari latar belakang tersebut, penulis berkeinginan untuk melakukan penelitian dalam mengungkap teori Capital Budgeting sebagai rekomendasi untuk diimplementasikan pada analisis investasi pada Hotel Panorama Lembang.

Melihat kondisi pariwisata di Bandung yang kian membaik dari tahun ke tahun, seluruh industri jasa pariwisata termasuk Hotel Panorama Lembang juga tidak mau kalah dalam meramaikan persaingan dalam memasarkan produknya yang mampu memenuhi kebutuhan wisatawan yang datang ke Kota Bandung. Hotel Panorama Lembang merupakan salah satu usaha akomodasi di Bandung Utara yang berfokus pada segmen pengunjung MICE (meeting, incentive, convention, dan exhibition). Keberadaannya sebagai penyedia jasa penginapan, konvensi, serta pelayanan lainnya bagi wisatawan ternyata memberikan kontribusi bagi kegiatan pariwisata di kawasan Bandung Utara. Hotel Panorama Lembang dipilih sebagai tempat penelitian, karena memiliki sejumlah unit analisis yang menunjang bagi penelitian ini. Oleh karena perencanaan tersebut maka diperlukan pengkajian yang mendalam terhadap kelayakan pengembangan usaha di Hotel Panorama Lembang. Aspek penilaian yang dibutuhkan dalam penilaian kelayakan pendirian sebuah hotel menurut Husnan (2000:186) antara lain adalah:

\section{Aspek Pasar}

Berdasarkan atas jumlah wisatawan yang berkunjung untuk melakukan kegiatan MICE (Meeting, Incentive, Convention and Exhibition) yang berperan sebagai demand sedangkan jumlah fasilitas akomodasi yang tersedia untuk menangani pasar MICE tersebut adalah sebagai supply. 


\section{Aspek Hukum,}

Aspek yang menjadi landasan hukum yang mendasari pembuatan izin dari usaha perhotelan.

\section{Aspek Teknis}

Meliputi bangunan yang ada untuk mendukung operasional hotel tersebut, perbaikan yang dilakukan untuk menjadikan bangunan ini menjadi representatifuntuk dijadikan hotel, dan sistem pelayanan yang sesuai.

\section{Aspek Sosial Ekonomi}

Aspek yang menyangkut tentang dampak yang ditimbulkan dari perusahaan ini kepada masyarakat sekitarnya.

\section{Aspek Manajemen dan Sumber Daya Manusia}

Aspek yang menyangkut siapa dan bagaimana pelaksanaan operasional hotel tersebut nantinya.

\section{Aspek Keuangan}

Aspek yang menyangkut pendanaan yang diperlukan untuk mendirikan usaha perhotelan dan proyeksi pendapatan serta biaya-biaya dimana keputusan investasi dikatakan layak untuk dilaksanakan bilamana dapat memberikan keuntungan secara keuangan dan non keuangan. Secara keuangan dikatakan layak bilamana ada hasil lebih dari selisih besarnya hasil investasi terhadap biaya investasi. "

Berdasarkan keenam aspek tersebut, penelitian yang akan dilakukan oleh penulis ini lebih menekankan kepada aspek proyeksi keuangan dikarenakan unit analisis yang mendukung untuk dilaksanakannya kajian pada aspek tersebut dan kondisi objek penelitian yang membutuhkan pengkajian lebih mendalam pada aspek keuangan.

Analisis yang lazim dilakukan untuk menilai kelayakan sebuah usaha hotel dalam ha] investasi adalah Capital Budgeting, namun demikian konsep capital budgeting masih belum banyak diterapkan oleh perusahaan sebagai alat analisis terhadap penilaian kelayakan investasi perusahaan. Konsep Capital Budgeting memperhatikan secara adil ekspektasi penyandang dana. Tidak seperti ukuran kinerja konvensional, konsep Capital Budget dapat berdiri sendiri tanpa perlu analisa perbandingan dengan perusahaan sejenis ataupun membuat analisa kecenderungan (trend). Pengertian Capital Budget menurut Schmidgall (1997:413) adalah "Capital Budgeting is the process of determining the amount to spend on fixed assets and which fixed assets to purchase".

Capital Budget berusaha mengukur nilai tambah yang dihasilkan perusahaan dengan memperhatikan biaya modal yang meningkat, karena biaya modal menggambarkan risiko perusahaan. Metode Capital Budget akan sesuai dengan kepentingan para investor dikarenakan para investor akan memfokuskan pada prospek keuntungan di masa yang akan datang dan perkembangan selanjutnya untuk mengetahui jaminan investasinya. Selain itu, jika suatu perusahaan dapat menciptakan nilai tambah bagi para investor, berarti mereka akan mendapatkan pengembalian yang lebih besar dibandingkan pada saat mereka berinvestasi.

Adapun beberapa model untuk pengukuran kelayakan suatu investasi yaitu dengan metode Capital Budgeting menurut Chatfield dan Dalbor (2005:205) adalah sebagai berikut: 1. "Profitability Index (PI) 
Profitability Index is constructed by taking ratio the ratio of the benefits to the cost.

\section{Payback Period (PP)}

Payback Period is the amount of time required for the net cash flows to recover the net investment. If the calculated payback period is equal to or less then payback objective then the project is accepted.

\section{Net Present Value Model (NPV)}

Net present value is the sum of the present values of the net cash flows discounted at the required rate of return minus the net investment, the project accepted if the net present value is equal to or greater than zero.

\section{Internal Rate of Return (IRR)}

IRR model is the rate of return of causing the project net present value to equal zero, a project internal rate of return is compared to the project required rate of return. If the internal rate of return exceeds the required rate of return, the project is acceptable."

Berdasarkan penelitian internasional yang dilakukan oleh Project Development Assistance Center Regional Development Council XI, Davao City (2002) dengan penelitian tentang studi kelayakan dukungan infrastruktur pada Program Ekonomi di Kota Sarangani, Davao Del Sur, Filipina. Dari hasil penelitian diketahui bahwa biaya proyek adalah 48,88 juta peso dengan deskripsi proyek adalah pengembangan kompleks pelabuhan di Barangay Mabila, reklamasi daerah yang dekat dengan pantai, penambahan dan peningkatan dermaga dan jalan yang melintasi daerah rawa-rawa dan pembangunan beberapa fasilitas tambahan seperti gedung administrasi, terminal penumpang, rumah makan, kamar yang nyaman dan ruang jaga. Dari hasil kelayakannya dapat diketahui bahwa dari sektor public dengan NPV Keuangan dengan $12 \%$ IR adalah -22 juta peso, IRR 0,5 \%, NPV ekonomi dengan 15 SDR adalah 139,2 juta peso dan IRR ekonomi $70 \%$ sedangkan untuk sektor privat dapat diketahui NPV dengan 16 IR sebesar 7,1 juta pcso dan IRR $25,06 \%$.

Arya Wijaya (2009) menyatakan dari penelitian tentang studi kelayakan penambahan bungalow pada PT Sari Ater adalah dari aspek pasar dan pemasaran dimana potensi penambahan bungalow pada PT Sari Ater yang cukup besar dapat dilihat dari tingkat hunian bungalow pada tahun 2005 sampai 2008, permintaan biro perjalanan rekanan dan tingkat kunjungan wisatawan ke Sari Ater Resort. Positioning perusahaan ditentukan berdasarkan diferensiasi produk, jasa, personil dan citra, dengan pangsa sasaran dan target penjualan yang ditetapkan oleh pemegang saham agar memberikan keuntungan investasi, dengan segmentasi dan target pasar perusahaan adalah wisatawan yang berkunjung berdasarkan data historis yang mengalami peningkatan dari tahun ketahun. Strategi pemasaran yang digunakan ialah mempertahankan tingkat kepuasan yang tinggi, relationship marketing dan penyiapan produk komplementer dengan konsep one stop visiting. Strategi penetapan harga yang digunakan adalah perceived value pricing yaitu harga ditentukan oleh kesan pembeli terhadap produk yang ditawarkan. Hasil yang diperoleh dari penelitian dapat diketahui dari aspek keuangan dimana payback period investasi bungalow selama 5 tahun, tergolong menguntungkan karena payback period nya lebih pendek daripada yang diisyaratkan oleh pemilik modal yaitu 8 tahun, NPV positif dan lebih besar daripada nol sebesar Rp.9.317.999.029,-menunjukkan bahwa investasi penambahan bungalow akan meningkatkan keuntungan pemilik modal, PI sebesar 2,07 lebih besar dari 1, menunjukkan bahwa usulan investasi bungalow tersebut dapat diterima, IRR sebesar $26,11 \%$ lebih besar daripada biaya modal yang dipandang layak oleh pemilik modal 
sebesar 15\%. Hal ini menunjukkan bahwa rencana investasi tersebut dinilai menguntungkan, ARR sebesar 37,76\% lebih besar daripada patokan ARR yang ditentukan investor sebesar $15 \%$ sehingga dari segi profitabilitas, proyek investasi tersebut layak untuk dilaksanakan dan hasil analisis sensitivitas menunjukkan bahwa variabel pendapatan sewa bungalow merupakan variabel yang sangat peka terhadap keberhasilan rencana investasi penambahan bungalow.

\section{B. METODE PENELITIAN}

Jenis penelitian yang digunakan dalam penelitian ini adalah jenis deskriptif analitik. Jenis deskriptif digunakan untuk tujuan membuat deskripsi gambaran secara sistematis, faktual dan akurat mengenai fakta -fakta serta sifat dan hubungan dengan fenomena yang diselidiki. Penelitian deskriptif yang dilakukan adalah dengan pendekatan studi survei dimana data yang diperoleh selama penelitian tersebut diolah, dianalisis serta diproses lebih lanjut berdasarkan teori yang telah dipelajari. Hal ini bertujuan untuk memperoleh deskripsi gambaran tentang aspek keuangan yang juga memiliki empat sub variabel yaitu profitability index, payback period, net present value, dan internal rate of return. Kedua aspek tersebut kemudian akan dinilai kaitannya dengan pengembangan usaha yang akan dilakukan oleh pihak Hotel Panorama Lembang.

Untuk memperoleh data yang dibutuhkan, penulis menggunakan alat pengumpul data sebagai berikut :

a. Studi Kepustakaan

Studi ini dilakukan dengan mencari sumber data melalui buku, literatur, referensi, maupun hasil penelitian sejenis yang berkaitan dengan masalah yang diteliti.

\section{b. Studi Dokumentasi}

Teknik pengumpulan data dengan mempelajari naskah, laporan, dokumen yang berhubungan dengan masalah yang sedang diteliti.

\section{c. Studi Survei}

Studi ini dilakukan untuk pengumpulan data yang luas dan banyak, studi ini merupakan bagian yang bertujuan untuk mencari kedudukan (status), fenomena, gejala, dan menentukan kesamaan status dengan cara membandingkannya dengan standar yang sudah ditentukan. Dalam metode survei ini data yang didapatkan oleh penulis adalah bersumber dari Income Statement Hotel Panorama Lembang dari tahun 2008 sampai dengan 2015.

\section{d. Studi Lapangan}

Pengumpulan data dan informasi yang diperoleh secara langsung di lokasi penelitian dengan menggunakan cara sebagai berikut:

\section{Wawancara}

Wawancara menurut Cahyono (2006:40) adalah: "Proses interaksi dan komunikasi untuk memperoleh keterangan untuk tujuan penelitian dengan cara tanya ja wab sambil tatap muka dengan menggunakan panduan wawancara". Penulis melakukan pembicaraan atau tanya jawab secara langsung dengan Accounting Manager Hotel Panorama Lembang sesuai dengan masalah yang dibahas sehingga data yang diperoleh dapat dipertanggungjawabkan kebenarannya dan relevan dengan permasalahan yang diangkat.

\section{Observasi}


Penulis melakukan pengamatan secara langsung terhadap objek yang diteliti. Observasi menurut Kusmayadi dan Sugiarto (2000:84) adalah: "Cara pengumpulan data dengan menggunakan jalan mengamati, meneliti, atau mengukur kejadian yang sedang berlangsung". Alasan penulis melakukan observasi karena datanya bersifat fakta sesuai keadaan sebenarnya. Observasi memiliki keuntungan karena data yang segar dalam artian data yang dikumpulkan diperoleh dari subjek pada saat terjadinya tingkah laku dan keabsahan alat ukur dapat diketahui secara langsung. Data yang yang diteliti secara langsung adalah laporan keuangan yang berhubungan dengan keputusan investasi yang erat hubungannya dengan kinerja keuangan yang ada di Hotel Panorama Lembang.

\section{HASIL DAN ANALISIS}

Kelayakan investasi Hotel Panorama Lembang berdasarkan proyeksi keuangan yang diteliti dinyatakan memiliki kelayakan investasi yang baik. Dari beberapa faktor pembentuk keputusan tersebut dan dibantu dengan menggunakan teknik analisis capital budgeting maka didapatkan basil sebagai berikut:

\section{Metode Discounted Payback Period (DPP)}

Hasil perhitungan pihak Hotel Panorama Lembang menggunakan metode Discounted Payback Period menunjukkan bahwa investasi akan kembali setelah 8 tahun 2 bulan 5 hari; sedangkan dari hasil perhitungan penulis dengan metode yang sama didapatkan bahwa investasi akan kembali setelah 6 tahun 11 bulan 19 hari. Berdasarkan analisis diatas ditemukan bahwa pengembalian modal investasi hasil perhitungan penulis memang membutuhkan waktu yang lebih lambat, hal ini disebabkan oleh adanya perbedaan hasil perhitungan net cash flow, perbedaan komponen other income, dan komponen cost and expenses yang nilainya lebih rendah dari pihak Hotel Panorama Lembang. Menurut kriteria penilaian metode discounted payback period adalah rencana investasi yang akan dilakukan berada dalam kriteria layak untuk dilaksanakan. Hal ini dapat dijelaskan pada tabel berikut ini.

Tabel 2

Hasil Penghitungan Discounted Payback Period Hotel Panorama

Lembang Pay Back period Method

\begin{tabular}{|c|c|c|c|c|c|}
\hline Year & $\begin{array}{c}\text { Operating } \\
\text { Cash Flow }\end{array}$ & $\begin{array}{c}\text { Terminal } \\
\text { Cash Flow }\end{array}$ & $\begin{array}{c}\text { Discounted } \\
\text { Factorl2\% }\end{array}$ & Present Value & Balance \\
\hline & & & & & $6,998,000,000$ \\
\hline 2016 & $39,257,503$ & & 0.89286 & $35,051,342$ & $6,962,948,658$ \\
\hline 2017 & $266,258,909$ & & 0.79719 & $212,259,972$ & $6,750,688,686$ \\
\hline 2018 & $684,354,683$ & & 0.71178 & $487,110,146$ & $6,263,578,540$ \\
\hline 2019 & $290,715,370$ & & 0.63552 & $184,754,874$ & $6,078,823,667$ \\
\hline 2020 & $1,456,699,802$ & & 0.56743 & $826,570,588$ & $5,252,253,079$ \\
\hline 2021 & $2,032,238,448$ & & 0.50663 & $1,029,595,243$ & $4,222,657,835$ \\
\hline 2022 & $3,867,139,680$ & & 0.45235 & $1,749,297,600$ & $2,473,360,235$ \\
\hline 2023 & $5,172,206,733$ & & 0.40388 & $2,088,967,551$ & $384,392,684$ \\
\hline 2024 & $5,921,279,166$ & & 0.36061 & $2,135,272,628$ & $-1,750,879,944$ \\
\hline 2025 & $6,886,826,888$ & & 0.32197 & $2,217,373,943$ & $-3,968,253,887$ \\
\hline 2025 & Book Value & $2,124,596,023$ & 0.32197 & $684,063,058$ & $-4,652,316,945$ \\
\hline 2025 & $\begin{array}{c}\text { Working } \\
\text { Capital }\end{array}$ & $1,000,000,000$ & 0.32197 & $321,973,237$ & $-4,974,290,181$ \\
\hline
\end{tabular}

Somber: Hotel Panorama Lembang, 2015.

18 | Jurnal Kepariwisataan: Destinasi, Hospitalitas dan Perjalanan, Volume 2 Nomor 1, 2018: 13-23 
Tabel 3

Hasil Penghitungan Discounted Payback Period Hasil Olahan Penulis

Pay Back period Method

\begin{tabular}{|c|c|c|c|c|c|}
\hline Year & $\begin{array}{c}\text { Operating } \\
\text { Cash Flow }\end{array}$ & $\begin{array}{c}\text { Terminal } \\
\text { Cash Flow }\end{array}$ & $\begin{array}{c}\text { Discounted } \\
\text { Factor (12\%) }\end{array}$ & Present Value & Balance \\
\hline & & & & & $6,648,000,000$ \\
\hline 2016 & $803,094,553$ & & 0.89286 & $717,048,708$ & $5,930,951,292$ \\
\hline 2017 & $1,013.344,295$ & & 0.79719 & $807,831,868$ & $5,123,119,424$ \\
\hline 2018 & $1.235,306,280$ & & 0.71178 & $879,266,610$ & $4,243,852,814$ \\
\hline 2019 & $669,560,651$ & & 0.63552 & $425,517,898$ & $3,818,334,916$ \\
\hline 2020 & $1,736,558,461$ & & 0.56743 & $985,369,907$ & $2,832,965,008$ \\
\hline 2021 & $2,270,532,243$ & & 0.50663 & $1,150,322,296$ & $1,682,642,712$ \\
\hline 2022 & $3,836,550,751$ & & 0.45235 & $1,735,460,722$ & $-52,818,009$ \\
\hline 2023 & $4,855,914,337$ & & 0.40388 & $1,961,222,357$ & $-2,014,040,367$ \\
\hline 2024 & $5,347,473,425$ & & 0.36061 & $1,928,352,525$ & $-3,942,392,892$ \\
\hline 2025 & $5,845,967,114$ & & 0.32197 & $1,882,244,953$ & $-5,824,637,845$ \\
\hline 2025 & Book Value & $2,124,596,023$ & 0.32197 & $684,063,058$ & $-6,508,700,903$ \\
\hline 2025 & $\begin{array}{c}\text { Working } \\
\text { Capital }\end{array}$ & $650,000,000$ & 0.32197 & $209,282,604$ & $-6,717,983,506$ \\
\hline
\end{tabular}

Sumber. Hasil Olahan Penulis, 2015.

\section{Metode Net Present Value (NPV)}

Berdasarkan hasil analisis penulis berdasarkan metode net present value didapatkan hasil perhitungan pihak Hotel Panorama Lembang didapatkan nilai NPV sebesar Rp. 4.974.290.181. Sedangkan berdasarkan hasil perhitungan oleh penulis didapatkan nilai NPV, yaitu sebesar Rp. 6.7] 7.983.506. Dad kedua perhitungan tersebut maka ditemukenali adanya varian dengan nilai selisih sebesar Rp. 1,743,693,325,-. Nilai selisih ini muncul sebagai hasil selisih perhitungan net present value antara pihak manajemen Hotel Panorama Lembang dan penulis, angka selisih ini disebabkan oleh adanya perbedaan perhitungan hasil net cash flow yang dihasilkan kedua belah pihak. Hal ini merupakan dampak dari tidak digunakannya metode dah teori yang sesuai dan relevan oleh pihak Hotel Panorama Lembang sehingga menyebabkan ketidak akuratan dalam hasil penghitungan net present value tersebut. Secara keseluruhan hasil penilaian metode net present value baik yang dilakukan oleh pihak Hotel Panorama Lembang maupun penulis berada dalam penilaian atau kategori layak untuk dilaksanakan. Hal ini dapat dijelaskan pada tabel berikut ini.

Tabel 4

Hasil Penghitungan Net Present Value Hotel Panorama Lembang

\begin{tabular}{|c|c|c|c|c|}
\hline Year & Operating Cash Flow & $\begin{array}{c}\text { Terminal Cash } \\
\text { Flow }\end{array}$ & Discounted Factor & Present Value \\
\hline 2016 & $39,257,503$ & & 0.89286 & $35,051,342$ \\
\hline
\end{tabular}




\begin{tabular}{|c|c|c|c|c|}
\hline 2017 & $266,258,909$ & & 0.79719 & $212,259,972$ \\
\hline 2018 & $684,354,683$ & & 0.71178 & $487,110,146$ \\
\hline 2019 & $290,715,370$ & & 0.63552 & $184,754,874$ \\
\hline 2020 & $1,456,699,802$ & & 0.56743 & $826,570,588$ \\
\hline 2021 & $2,032,238,448$ & & 0.50663 & $1,029,595,243$ \\
\hline 2022 & $3,867,139,680$ & & 0.45235 & ممع حمد ممح \\
\hline 2023 & $5,172,206,733$ & & 0.40388 & $2,088,967,551$ \\
\hline 2024 & $5.921,279,166$ & & 0.36061 & $2,135,272,628$ \\
\hline 2025 & $6,886,826,888$ & & 0.32197 & $2,217,373,943$ \\
\hline 2025 & Book Value & $2,124,596,023$ & 0.32197 & $684,063,058$ \\
\hline 2025 & Working Capital & $1,000,000,000$ & 0.32197 & $321,973,237$ \\
\hline \multicolumn{5}{|c|}{ Sumber: Hotel Panorama Lembang, 2015.} \\
\hline & & & Initial Investment & $6,998,000,000$ \\
\hline & & & Net Present Value & $4,974,290,181$ \\
\hline
\end{tabular}

Tabel 5

Hasil Pen ahitunaan Net Present Value Hasil Olahan Penulis

\begin{tabular}{|c|c|c|c|c|}
\hline Year & Operating Cash Flow & $\begin{array}{c}\text { Terminal Cash } \\
\text { Flow }\end{array}$ & Discounted Factor & Present Value \\
\hline 2016 & $803,094,553$ & & 0.89286 & $717,048,708$ \\
\hline 2017 & $1,013,344,295$ & & 0.79719 & $807,831,868$ \\
\hline 2018 & $1,235,306,280$ & & 0.71178 & $879,266,610$ \\
\hline 2019 & $669,560,651$ & & 0.63552 & $425,517,898$ \\
\hline 2020 & $1,736,558,461$ & & 0.56743 & $985,369,907$ \\
\hline 2021 & $2,270,532,243$ & & 0.50663 & $1,150,322,296$ \\
\hline 2022 & $3,836,550,751$ & & 0.45235 & $1,735,460,722$ \\
\hline 2023 & $4,855,914,337$ & & 0.40388 & $1,961,222,357$ \\
\hline 2024 & $5.347,473,425$ & & 0.36061 & $1,928,352,525$ \\
\hline 2025 & $5,845,967,114$ & & 0.32197 & $1,882,244,953$ \\
\hline 2025 & Book Value & $2,124,596,023$ & 0.32197 & $684,063,058$ \\
\hline 2025 & Working Capital & $650,000,000$ & 0.32197 & $209,282,604$ \\
\hline \multicolumn{4}{|c|}{ Sumber: Hasil Olahan Penulis, 2015.} & \multirow[t]{2}{*}{$13,365,983,506$} \\
\hline & & & Initial Investment & \\
\hline & & & Net Present Value & $6,717,983,506$ \\
\hline
\end{tabular}

\section{Metode Internal Rate Of Return (IRR)}

Berdasarkan hasil analisis penulis berdasarkan metode internal rate of return didapatkan hasil perhitungan IRR oleh pihak Hotel Panorama Lembang adalah sebesar 18.947\%. Sedangkan berdasarkan hasil perhitungan penulis didapatkan nilai IRR sebesar $23.930 \%$, nilai tersebut menghasilkan varian dengan nilai dengan nilai selisih perhitungan sebesar $4.9829 \%$. Nilai ini muncul sebagai hasil selisih perhitungan internal rate of return antara pihak Hotel Panorama Lembang dan penulis, angka selisih ini muncul disebabkan oleh adanya perbedaan hasil perhitungan net cash flow yang dihasilkan kedua belah 20 Jurnal Kepariwisataan: Destinasi, Hospitalitas dan Perjalanan, Volume 2 Nomor 1, 2018: 13-23 
pihak. Net cash flow pihak Hotel Panorama Lembang kurang handal dari segi kekuatan dan handal keakuratannya. Hal ini ditambah pula dengan kondisi biaya investasi awal (initial investment) dari pihak Hotel Panorama Lembang yang lebih besar, serta penggunaan modal kerja (working capital) yang lebih besar dibandingkan dengan hasil olahan penulis. Lebih rendahnya nilai IRR yang dihasilkan oleh pihak Hotel Panorama Lembang dibandingkan penulis akan berdampak buruk terhadap hasil pencapaian yield investasi dari pihak Hotel Panorama Lembang. Lebih tingginya nilai IRR basil olahan dari penulis dibandingkan basil perhitungan pihak Hotel Panorama Lembang adalah dikarenakan penggunaan teori dan metode yang sesuai kaidah yang berlaku dan tcpat guna sehingga basil yang diharapkan dari investasi tersebut dapat tercapai. Berdasarkan basil analisis penulis sebelumnya perhitungan internal rate of return dari kedua belah pihak, baik pihak Hotel Panorama Lembang maupun penulis memiliki basil perhitungan IRR lebih besar dari rate of return yaitu sebesar (12\%) maka hal ini berarti usulan investasi menurut kriteria penilaian metode internal rate of return layak untuk dilaksanakan. Hal tersebut telah penulis gambarkan pada tabel berikut ini.

Tabel 6

Hasil Penghitungan Internal Rate Of Return Hotel Panorama Lembang

\begin{tabular}{|c|c|c|c|}
\hline Year & Net Cash Flow & Discounted Factor:: & \multirow{2}{*}{ Present Value } \\
\hline 2016 & $39,257,503$ & 0.840707648 & \multirow{2}{*}{$33,004,083$} \\
\hline 2017 & $266,258,909$ & 0.70678935 & \\
\hline 2018 & $684,354,683$ & 0.594203212 & $406,645,751$ \\
\hline 2019 & $290,715,370$ & 0.499551185 & $145,227,208$ \\
\hline 2020 & $1,456,699,802$ & 0.419976502 & $611,779,687$ \\
\hline 2021 & $2,032,238,448$ & 0.353077457 & $717,537,583$ \\
\hline 2022 & $3,867,139,680$ & 0.296834919 & $1,147,902,092$ \\
\hline 2023 & $5,172,206,733$ & 0.249551386 & $1,290,731,361$ \\
\hline 2024 & $5,921,279,166$ & 0.209799759 & $1,242,282,943$ \\
\hline 2025 & $6,886,826,888$ & 0.176380262 & $1,21.4,700,331$ \\
\hline \multicolumn{2}{|l|}{ Sumber: Hotel Panorama Lembang, 2015.} & $6,998,000,000$ \\
\hline
\end{tabular}

Tabel 7

Hasil Penghitungan Internal Rate Of Return Hasil Olahan Penulis

\begin{tabular}{|c|c|c|c|}
\hline Tabun & & $\begin{array}{c}\text { Net Cdsh FlowPresent } \\
\text { Discounted Factor }\end{array}$ & $\begin{array}{c}\text { Valu } \\
e-\end{array}$ \\
\hline 2016 & $803,094,553$ & 0.806905142 & $648,021,125$ \\
\hline 2017 & $1,013,344,295$ & 0.651095909 & $659,784,325$ \\
\hline 2018 & $1,235,306,280$ & 0.525372637 & $648,996,118$ \\
\hline 2019 & $669,560,651$ & 0.423925882 & $283,844,090$ \\
\hline 2020 & $1,736,558,461$ & 0.342067975 & \multirow{2}{*}{$594,021,036$} \\
\hline 2021 & $2,270,532,243$ & 0.276016408 & \\
\hline 2022 & $3,836,550,751$ & 0.222719059 & \multirow{2}{*}{$854,472,972$} \\
\hline 2023 & $4,855,914,337$ & 0.179713154 & \multirow{2}{*}{$872,671,680$} \\
\hline 2024 & $5,347,473,425$ & 0.145011468 & \\
\hline
\end{tabular}




\begin{tabular}{|c|c|c|c|}
\hline 2025 & $5,845,967,114$ & 0.117010499 & $684,039,530$ \\
\hline
\end{tabular}

\section{4. $\quad$ Metode Profitability Index (PI)}

Berdasarkan basil perhitungan Profitability Index pihak Hotel Panorama Lembang didapatkan basil index sebesar 1.7108. Sedangkan basil perhitungan penulis berdasarkan metode profitability index didapatkan index sebesar 2.0105.Berdasarkan basil analisis penulis berdasarkan metode profitability index didapatkan varian dengan nilai selisih sebesar 0,30. Nilai index selisih ini muncul sebagai hasil perbedaan perhitungan profitability index antara pihak Hotel Panorama Lembang dan penulis, index selisih ini muncul disebabkan oleh adanya perbedaan net cash flow yang dihasilkan kedua belah pihak baik pihak, manajemen Hotel Panorama Lembang maupun pihak penulis. Hal mendasar lainnya yang menyebabkan adanya perbedaan basil perhitungan profitability index tersebut adalah adanya perbedaan investasi awal (intial investment) antara pihak Hotel Panorama Lembang dan pihak penulis. Tingkat profitability index yang dihasilkan oleh pihak Hotel Panorama Lembang menghasilkan nilai yang lebih rendah dari basil perhitungan penulis, adalah dikarenakan pihak hotel yang memiliki nilai present value yang kurang kuat dan handal dalam menghasilkan keuntungan dari usulan investasi yang diusulkan. Sedangkan basil perhitungan penulis memiliki nilai yang lebih tinggi dikarenakan digunakannya teori dan metode yang sesuai dengan kaidah standar suatu studi kelayakan. Dengan digunakannya teori dan metode yang sesuai dan relevan tersebut, maka akan menghasilkan perhitungan present value yang ideal dan dapat menghasilkan keuntungan yang lebih besar dari investasi yang direncanakan tersebut. Secara keseluruhan dari penjelasan analisis tersebut maka dapat disimpulkan usulan investasi menurut kriteria penilaian metode profitability index adalah layak untuk dilaksanakan. Akan tetaoi dari segi basil keuntungan nantinya yang akan diperoleh dari usulan investasi, basil penilaian profitability index dari pihak penulis dapat lebih menghasilkan keuntungan dibandingkan basil penilaian pihak Hotel Panorama Lembang dikarenakan hasilnya yang lebih besar. Untuk lebih jelasnya dapat diamati pada tabel berikut ini.

Tabel 8. Hasil Penghitungan Profitability Index Hotel Panorama Lembang

\begin{tabular}{|l|c|}
\hline Total Present Value & $11,972,290,181$ \\
\hline Initial Investment & $6,998,000,000$ \\
\hline Net Present Value & $4,974,290,181$ \\
\hline Profitability Index & 1.7108 \\
\hline
\end{tabular}

Sumber: Hotel Panorama Lembang, 2015.

Tabel 9. Hasil Pen hitun an Protttabilitl. Index Hasil Olahan Penulis

\begin{tabular}{|l|c|}
\hline Total Present Value & $13,365,983,506$ \\
\hline Initial Investment & $6,648,000,000$ \\
\hline Net Present Value & $6,717,983,506$ \\
\hline Profitability Index & 2.0105 \\
\hline
\end{tabular}

Sumber: Hasil Olahan Penulis, 2015.

\section{SIMPULAN}

22 | Jurnal Kepariwisataan: Destinasi, Hospitalitas dan Perjalanan, Volume 2 Nomor 1, 2018: 13-23 
Berdasarkan hasil penelitian, dan pembahasan yang telah dilakukan, maka dapat diambil kesimpulan bahwa menurut empat macam metode capital budgeting yang digunakan untuk menilai kelayakan investasi kamar dan ballroom di Hotel Panorama Lembang, didapatkan bahwa keempat hasilnya adalah positif. Hal ini berarti setiap metode capital budgeting yang digunakan untuk menilai kelayakan investasi di Hotel Panorama Lembang bernilai positif. Dengan kata lain menurut keempat teknik perhitungan capital budgeting, pembangunan kamar dan ballroom di Hotel Panorama Lembang layak untuk dilaksanakan. Akan tetapi nilai hasil perhitungan dari pihak penulis selalu lebih besar dibandingkan dengan hasil perhitungan pihak Hotel Panorama Lembang, dari hal ini dapat diketahui Hotel Panorama Lembang memiliki ketidakoptimisan terhadap basil penilaian investasi yang dilakukan. Hal seperti ini akan berpengaruh buruk kepada kontinuitas keuntungan usaha dari Hotel Panorama Lembang. Pengaruh buruk tersebut timbul diakibatkan penetapan target pendapatan yang nantinya akan berdampak pada keuntungan usaha yang bersifat pesimistik. Sifat pesimistik ini dapat terlihat dari besaran angka penetapan target pendapatan usaha rendah, akan tetapi berdasarkan basil olahan data dari penulis pihak manajemen dapat lebih meningkatkan target tersebut.

Dari basil analisis yang telah dilakukan maka hasilnya menunjukkan bahwa investasi penambahan asset berupa pembangunan 16 unit kamar hotel dan ballroom yang dilakukan oleh Hotel Panorama Lembang akan dapat memberikan keuntungan bagi pihak hotel, oleh karena itu penambahan asset layak untuk dilakukan dan sebaiknya direalisasikan. Penambahan asset sebanyak 16 kamar dan ballroom ini diharapkan nantinya dapat menarik konsumen yang lebih banyak lagi dan hal ini akan mendatangkan keuntungan yang lebih besar kepada pihak Hotel Panorama Lembang. Untuk memperinci penyampaian saran ini, maka penulis membaginya kedalam tiga bagian, yakni saran konseptual, saran operasional, dan saran akademik.

\section{DAFTAR REFERENSI}

Alma, Buchari. 2004. Manajemen Pemasaran dan Pemasaran Jasa. Bandung: Alfabeta. Cahyono, Bambang Tri. 1996. Metodologi Riset Bisnis. Jakarta: IPWI.

Chatfield, Robert E. and Dalbor. 2005. Hospitality Financial Management. New Jersey: Prantice Hall. Coltman, Michael M and Jagels. 2004. Hospitality Management Accounting. New York: Van Nostrand Reinhold.

Halim, Abdul. 2005. Analisis Investasi. Malang: Salemba Empat.

Heizer, Jay dan Barry Render. 2006. Operations Management. Eighth Edition. New Jersey: Pearson International Edition.

Hurriyati, Ratih. 2010. Bauran Pemasaran Dan Loyalitas Konsumen. Bandung: Al fabeta.

Husnan, Suad dan Enny Pudjiastuti. 2000. Dasar-Dasar Manajemen Keuangan. Yogyakarta: AMP YKPN. 